\title{
GAMBARAN KEPUASAN PERNIKAHAN PADA WANITA KETURUNAN ARAB YANG MELAKUKAN PERNIKAHAN DENGAN ETNIS LAIN
}

\author{
Syarifah Ragoan ${ }^{1}$, \\ Vinaya Untoro ${ }^{2}$, \\ Diana Rita Ari \\ Fakultas Psikologi \\ Universitas Pancasila \\ J1. Srengseng Sawah, Jagakarsa, \\ Jakarta 12640, Indonesia \\ ${ }^{1}$ e-mail: syarifahragoan@ymail.com \\ ${ }^{2}$ e-mail:vi315naya@gmail.com
}

\begin{abstract}
The present study intends to describe the dynamics of marital satisfaction of women of Arabian descent who married a spouse of another ethnicity. The marriage of women of Arabian descent with someone from a different ethnicity is considered as breaking the cultural norms. In the present study, marital satisfaction consists of many aspects, namely communication, the personality of the spouse, the ability to solve conflicts, sexual relationship, leisure activity, the presence of children and parenting, financial management, role suitability, religious orientation, as well as family and friends. The present study employed qualitative methods with 2 participants. Participants were women of Arabian descent who married someone from another ethnicity for two to five years and at least graduated from high school. Data were gathered through interview and observation. The results showed that participants feel uncomfortable due to their marriage being disapproved by their extended family, however it does not seem to influence their marital satisfaction significantly. The most significant factor influencing marital satisfaction of both participants was financial or economic factor.
\end{abstract}

Keywords: marital satisfaction; Arabian descent women; interethnic marriage

Abstrak - Penelitian ini bertujuan untuk mengetahui gambaran dinamika kepuasan pernikahan pada wanita keturunan Arab yang melakukan pernikahan dengan etnis lain. Pernikahan wanita keturunan Arab dengan etnis di luar Arab dianggap bertentangan dengan adat istiadat. Kepuasan pernikahan pada penelitian ini dilihat dari beberapa aspek kepuasan pernikahan, di antaranya komunikasi, kepribadian pasangan, kemampuan menyelesaikan masalah, hubungan seksual, aktivitas waktu 
luang, kehadiran anak dan menjadi orangtua, mengatur keuangan, kesesuaian peran, orientasi keagamaan, serta keluarga dan teman. Penelitian ini menggunakan metode kualitatif dengan 2 partisipan. Karakteristik partisipan adalah wanita keturunan Arab yang menikah dengan etnis lain, usia pernikahan antara dua sampai lima tahun, dan tingkat pendidikan minimal SMA atau sederajat. Pengumpulan data diperoleh melalui wawancara dan observasi. Hasil penelitian menunjukkan adanya rasa ketidaknyamanan dalam rumah tangga ketika keluarga besar tidak menyetujui pernikahan partisipan, namun hal tersebut kurang memberikan pengaruh besar kepada kepuasan pernikahan kedua partisipan. Faktor yang berpengaruh besar dalam kepuasan pernikahan kedua partisipan adalah faktor ekonomi atau keuangan.

Kata Kunci: kepuasan pernikahan; wanita keturunan Arab; pernikahan antar etnik

\section{PENDAHULUAN}

Indonesia merupakan negara yang memiliki bermacam-macam suku bangsa, bahasa daerah, serta agama maupun budaya dengan keberagaman yang tinggi. Pada zaman modern ini, masih banyak kelompok masyarakat Indonesia yang melestarikan tradisi atau budaya yang mereka miliki; salah satunya yaitu kebudayaan Arab. Etnis Arab sebagian besar masih memegang teguh ajaranajaran dalam agama Islam dan tradisi-tradisi yang berlaku di kalangannya. Seperti yang dinyatakan oleh Van de Berg (1989), etnis Arab memiliki rasa kepemilikan (sense of belonging) yang sangat kental terhadap Islam yang berpengaruh terhadap nilai-nilai kebudayaan serta adab dan kebiasaan mereka sehari-hari, seperti pada adat pernikahan, pemakaman, kesenian daerah, dan berdagang.

Khusus terkait dengan adat pernikahan, keturunan Arab di Indonesia umumnya masih memegang teguh tradisi secara ketat mengenai pembatasan perjodohan yang mereka percayai hingga saat ini. Keturunan Arab percaya bahwa faktor nasab (keturunan) perlu mendapat perhatian khusus terhadap penentuan calon jodoh seseorang, sebab masalah ini banyak memengaruhi sifat, watak, dan karakter seseorang (Almasyhur, 2002). Wanita keturunan Arab kurang memiliki kebebasan untuk memilih dibandingkan laki-laki keturunan Arab. Salah satu tradisinya adalah keturunan Arab melarang wanita-wanita mereka menikah dengan laki-laki yang bukan keturunan Arab (non-Sayyid). Sayyid adalah sebutan laki-laki keturunan Arab yang memiliki ayah asli keturunan Arab dan ibu dari keturunan Arab ataupun dari suku lain, sedangkan Syarifah adalah sebutan wanita keturunan Arab yang memiliki ayah asli keturunan Arab dan ibu dari keturunan 
Arab ataupun dari suku lain. Dalam pernikahan, keturunan Arab menganut hukum adat patrilineal dimana setelah terjadinya pernikahan, istri ikut masuk kekerabatan suaminya.

Menurut Hisyam (dalam Assagaf, 2000), hanya pihak laki-laki Arab sajalah yang dapat meneruskan gelar kesayyidan, bukan Syarifah, maka dari itu lelaki Sayyid boleh menikah, baik dengan wanita keturunan Arab (Syarifah) ataupun wanita di luar keturunan Arab (non-Syarifah). Sebaliknya jika ada wanita keturunan Arab (Syarifah) yang menikah dengan laki-laki di luar Arab (non-Sayyid), umumnya akan tidak direstui oleh pihak keluarga inti ataupun keluarga besar karena dianggap sebagai pelanggaran (Assagaf, 2000). Kemudian Syarifah yang melakukan pelanggaran dalam pernikahan akan diberikan sanksi secara sosial, baik oleh keluarga mereka sendiri maupun kerabat lain.

Menurut kepercayaan keturunan Arab, apabila wanita keturunan Arab melanggar tradisi perrnikahan, seperti menikah di luar budayanya dan tanpa restu orangtua, umumnya akan dianggap mati, tidak pernah ada di dunia, serta diputuskan segala hubungan dengan mereka (Assagaf, 2000). Sanksi lain yang diperoleh apabila wanita keturunan Arab menikah dengan non-Sayyid adalah menjadi terhalang untuk mendapatkan warisan orangtuanya, dikarenakan menurut adat setempat, anak perempuan keturunan Arab yang berani menikahi laki-laki di luar etnisnya dianggap tidak pernah ada atau dianggap telah meninggal dunia (Mulia, 2012). Pada penelitian ini, peneliti tertarik untuk mengetahui lebih jauh terkait dengan kepuasan pernikahan pada wanita keturunan Arab (Syarifah) yang berani melanggar tradisi dengan menikah dengan laki-laki dari etnis lain (nonSayyid) karena hal yang dilakukan jelas telah melanggar tradisi kebudayaan Arab. Hal ini menarik, karena selain berbeda latar belakang etnis antara pasangan itu, pernikahan tersebut juga tidak di restui keluarga dan anggota kerabat.

Menurut Putranto (2013), hubungan pernikahan yang tidak direstui orang tua biasanya akan bermasalah dan hidup pun menjadi tidak nyaman. Sementara itu, berdasarkan studi literatur, kepuasan pernikahan yang rendah banyak ditemukan pada pernikahan yang berbeda ras atau etnis, agama, dan kelas sosial (Williams, Sawyer, \& Wahlstrom, 2006). Beberapa studi menemukan hasil yang hampir serupa bahwa pernikahan dengan perbedaan etnis atau ras lebih rentan terhadap konflik (Monahow; Spanier \& Glick, dalam Vaijayanthimala, Kumari, \& Panda, 2004). Sesuai dengan adat ketimuran seperti di Indonesia, pernikahan tidak hanya dilakukan diantara dua individu dalam ikatan yang sakral atau menurut hukum agama dan Negara saja, namun juga harus mendapat pengakuan dari para anggota kerabat keluarga. Terlebih jika pasangan pernikahan tersebut berasal 
dari latar belakang etnis yang berbeda, akan banyak dijumpai berbagai jenis perbedaan seperti nilainilai budaya, sikap, keyakinan, prasangka, dan stereotype (Matsumoto \& Juang, 2008). Kemungkinan konflik dan masalah yang dihadapi oleh wanita keturunan Arab yang melakukan pernikahan pada etnis lain (non Arab) diasumsikan lebih besar dan berpengaruh terhadap kepuasan pernikahannya. Menurut Olson dan Fowers (1989), kepuasan pernikahan adalah evaluasi terhadap area-area dalam pernikahan. Area ini mencakup komunikasi yang menyenangkan, kehidupan beragama yang baik, cara mengisi waktu senggang, menyelesaikan masalah, mengatur keuangan, kualitas dan kuantitas hubungan seksual, hubungan baik dengan keluarga dan teman, pengasuhan terhadap anak, menerima sifat pasangan, dan berbagi peran antara suami dan istri dalam pernikahannya.

Dalam menjalin sebuah pernikahan yang permanen, kepuasan pernikahan adalah hal yang sangat penting dirasakan oleh individu-individu yang bersangkutan. Hal ini sesuai dengan survei yang dilakukan oleh Waite dan Gallagher (2000), yang menunjukkan bahwa 93\% responden menyatakan salah satu tujuan hidup mereka yang terpenting adalah memiliki pernikahan yang memuaskan. Cherlin (dalam Waite \& Gallagher, 2000) pun mengemukakan hal yang serupa. Menurut Cherlin, zaman sekarang ini pasangan cenderung mengevaluasi pernikahan mereka dan jika tidak memuaskan, mereka memilih untuk bercerai. Kemudian pasangan yang berada dalam pernikahan yang tidak memuaskan memiliki faktor risiko lebih besar untuk mengalami sakit dan mengurangi kesempatan hidup mereka (Gove, Style, \& Hughes, dalam Santrock, 2006).

Menurut Duvall dan Miller (1985), ada dua faktor yang memengaruhi kepuasan pernikahan, yaitu faktor-faktor yang muncul sebelum pernikahan dan faktor-faktor yang muncul setelah pernikahan. Faktor sebelum pernikahan antara lain pernikahan orangtua, masa kanak-kanak, pendidikan, berpacaran, dan usia saat melakukan pernikahan. Sementara itu, yang termasuk dalam faktor-faktor selama pernikahan antara lain komunikasi antara pasangan, anak dalam keluarga, kehidupan seksual, kesamaan minat, latar belakang sosial budaya, dan perekonomian keluarga.

Berdasarkan penuturan di atas, penelitian yang dilakukan akan menggunakan pendekatan kualitatif karena bertujuan untuk mengetahui gambaran kepuasan pernikahan pada wanita Keturunan Arab yang telah melanggar tradisi budaya dengan menikahi pria non Arab secara mendalam dan mendetail. Sesuai dengan pendapat Poerwandari (2007) bahwa penelitian kualitatif dimaksudkan untuk menyelidiki kasus dalam jumlah kecil secara mendalam dan mendetail. 


\section{METODE}

\section{Partisipan}

Partisipan yang digunakan dalam penelitian ini adalah terdiri dari dua wanita keturunan Arab yang memiliki ayah keturunan Arab dan ibu dari keturunan Arab dan non Arab, usia pernikahan minimal dua sampai lima tahun, serta berpendidikan minimal SMA atau sederajat. Pemilihan partisipan dilakukan dengan teknik purposive sampling. Prosedur rekrutmen partisipan dalam penelitian ini adalah pengambilan partisipan berdasarkan teori atau berdasarkan konstruk operasional (theory based atau operational construct sampling).

\section{Desain}

Pendekatan yang digunakan dalam penelitian ini adalah pendekatan kualitatif. Dalam pendekatan kualitatif dilakukan pemahaman yang menyeluruh mengenai fenomena yang diteliti (Poerwandari, 2007). Metode pengumpulan data yang digunakan dengan wawancara dan observasi dengan menggunakan daftar pertanyaan umum dan memiliki kemungkinan probing dari setiap pertanyaan, sedangkan observasi bertujuan untuk mendeskripsikan setting, aktivitas, dan makna kejadian dari pihak pengamat untuk melengkapi hasil wawancara. Secara spesifik, penelitian ini termasuk studi kasus. Studi kasus adalah fenomena khusus yang hadir dalam suatu konteks yang dibatasi (Poerwandari, 2007). Dalam penelitian ini kasus berupa individu dengan karakteristik khusus yaitu wanita Arab yang menikah dengan etnis non Arab.

\section{Prosedur}

Penelitian ini dimulai dengan menyusun pedoman wawancara sesuai dengan kajian pustaka yang terkait dengan kepuasan pernikahan. Dilanjutkan dengan mencari partisipan sesuai dengan kriteria yang ditetapkan, menjalin rapport dan melakukan wawancara dan observasi.

\section{Teknik Analisis}

Analisis dilakukan dengan mengumpulkan semua data hasil wawancara dan observasi, membuat verbatim hasil wawancara, mengidentifikasi tema-tema yang muncul, membuat 
rangkuman kasus tiap partisipan, melakukan analisis awal, serta menuliskan hasil penelitian (Poerwandari, 2007).

\section{ANALISIS DAN HASIL}

Tabel 1.

Karakteristik Partisipan

\begin{tabular}{lllll}
\hline Aspek & \multicolumn{1}{c}{$\begin{array}{c}\text { Partisipan 1 } \\
\text { (B) }\end{array}$} & \multicolumn{1}{c}{$\begin{array}{c}\text { Suami Partisipan 1 } \\
(\mathbf{A})\end{array}$} & $\begin{array}{c}\text { Partisipan 2 } \\
(\mathbf{H B})\end{array}$ & $\begin{array}{c}\text { Suami Partisipan 2 } \\
(\mathbf{P})\end{array}$ \\
\hline $\begin{array}{l}\text { Usia } \\
\begin{array}{l}\text { Pendidikan } \\
\text { terakhir }\end{array}\end{array}$ & 24 tahun & 26 tahun & 24 tahun & 25 tahun \\
Suku & SMA & D3 & SMA & S1 \\
Pekerjaan & Arab-Sunda & $\begin{array}{l}\text { Sunda } \\
\text { Sales Promotion Boy }\end{array}$ & $\begin{array}{l}\text { Arab } \\
\text { Ibu rumah tangga }\end{array}$ & Jawa \\
\hline
\end{tabular}

\section{Gambaran Partisipan 1}

B adalah seorang wanita keturunan Arab yang berusia 24 tahun yang memiliki wajah oval, berkulit putih, rambut tebal berwarna hitam dan panjang. B adalah anak kedua dari empat bersaudara. B memiliki anak perempuan yang berusia 1 tahun. Kegiatan sehari-hari B adalah sebagai ibu rumah tangga. Usia pernikahan B baru berjalan 2 tahun. Selama 3 tahun lamanya berpacaran, hubungan mereka tidak diketahui oleh pihak keluarga B. Selama berpacaran, B tidak pernah membicarakan status B sebagai keturunan Arab yang seharusnya memiliki pasangan hidup dengan satu etnis. Tidak lama kemudian hubungan mereka diketahui pihak keluarga B, yaitu ayah $\mathrm{B}$, berdasarkan pembicaraan tetangga yang sering melihat B bersama A di jalan dekat rumahnya. Pada saat itu juga ayah B geram dan tidak menyetujui hubungan tersebut, ayah B mengeluarkan pernyataan-pernyataan yang membuat B sakit hati. B pun hanya terdiam ketika ayahnya menyatakan pernyataan-pernyataan tersebut. Besoknya barulah B memberitahukan A mengenai tradisi wanita Arab harus menikah dengan etnis yang sama. Meskipun begitu, A tidak menyerah dan tetap mengajak B untuk melanjutkan ke jenjang pernikahan.

Dari pengamatan peneliti, keluarga B tergolong sebagai keluarga dengan ekonomi menengah ke bawah. Hal ini terlihat dari rumahnya yang tidak terlalu besar dan atapnya yang kurang terawat. Bisa terlihat juga pekerjaan ayah B sebagai tukang ojek. Alasan lain yang membuat B akhirnya memperjuangkan hubungan mereka sampai kejenjang pernikahan adalah B yang berpendapat bahwa laki-laki Arab, ketika menjalani pernikahan, kurang memiliki tanggung jawab terhadap keluarga. B melihat dari kebiasaan sehari-hari ayahnya sebagai tukang ojek, B merasa ayahnya kurang memiliki keinginan untuk bekerja keras dalam menafkahi keluarga. Sebagai 
contohnya, ayah B terlalu sering di rumah dibandingkan bekerja sebagai tukang ojek, kemudian B dan adiknya sering menunggak bayaran sekolah karena tidak adanya pemasukan untuk bayaran sekolah ataupun membeli keperluan rumah tangga. Anggapan B bahwa laki-laki Arab semuanya tidak memiliki tanggung jawab terhadap keluarga membuat B merasa tidak ada jaminan kebahagiaan ketika menikah dengan laki-laki Arab (Sayyid).

Meskipun awalnya tidak disetujui, namun A tidak menyerah mendekati keluarga B. Dimulai dengan sering berkunjung ke rumah B dengan alasan silaturahmi, sering membawa bingkisan dan akhirnya A menyanggupi untuk membayar listrik dan membantu uang belanja keluarga B. Hal inilah yang seiring berjalannya waktu membuat keluarga B merestui pernikahan B dengan A. Saat proses pernikahan berlangsung, pernikahan tersebut dilaksanakan di rumah orangtua B. Pihak keluarga besar B tidak satu pun hadir untuk menyaksikan pernikahan tersebut. B merasa kecewa dan sedih karena perlakuan keluarga besar yang begitu tidak memperdulikan pernikahan B. Setelah menikah, selain keluarga besar yang sudah menganggapnya tidak ada, B juga mengalami masalah dengan rumah tangganya. B merasa ada perubahan yang signifikan dari tingkah laku suaminya dengan B ataupun ke keluarga B. Kurang perhatian dan komunikasi dirasakan oleh B. A selalu memberi sesuatu untuk orangtua B ketika masih berpacaran dan awal pernikahan, namun setelah 1 tahun berjalannya pernikahan tidak pernah ada satu pemberian pun dari A. B merasa lebih baik menjalin hubungan saat waktu masih berpacaran dibandingkan ketika sudah menikah. Selain permasalahan di keluarga besarnya, B sampai saat ini memiliki permasalahan dengan orangtua suaminya. Sampai saat ini B masih menetap bersama orangtua suaminya. Orangtua suaminya, terutama ibu suaminya, tidak begitu menyukai B karena merasa bahwa B orang yang malas bekerja. Karena pada zaman A dan mantan kekasihnya itu masih menjalin hubungan, mantan A sering membantu pekerjaan rumah tangga yang membuat ibu A selalu senang melihat kehadirannya di rumah. Permasalahan bertubi-tubi menimpa B pada pernikahannya. B pun menyadari bahwa dibanding mantan A, B lebih jarang membantu pekerjaan rumah mertuanya.

Saat usia anaknya hampir 1 tahun, B memergoki suaminya berselingkuh dengan wanita lain. B merasa perilaku B yang membuat suaminya melakukan perselingkuhan itu, seperti ketika B diajak untuk melakukan hubungan seksual, B sering menolak ajakan suaminya kemudian kemungkinan karena B kurang memperhatikan suaminya ketika suami pulang kerja sehingga suami B merasa tidak mendapat perhatian penuh dari istrinya dan kurangnya mendapat kepuasan dari berhubungan seksual. B pun merasa malu dengan keluarga besar B kalau sampai B bercerai dengan 
suaminya karena awalnya B berjuang mempertahankan hubungannya sampai nekat menikah dengan suaminya yang bukan berasal dari keturunan Arab. Dia juga khawatir dengan pembiayaan hidup diri dan anaknya serta keluarga besar jika dia bercerai.

\section{Kepuasan Pernikahan Partisipan 1}

Berdasarkan aspek-aspek kepuasan pernikahan, dari segi kepribadian, komunikasi dan pemecahan masalah, suami B memiliki sifat pendiam, sedangkan gaya bicara B lebih dominan dari suaminya. Kesepakatan sulit diperoleh saat adu argumentasi dengan suami.

"laki gue orangnya pendiem, pacaran juga gitu. Guenya ceplas ceplos, ga enak kalo lagi ada masalah sama mertua minta bantuan supaya baean lagi, dianya iya iya aja. Kadang gue marah-marah, dia diem aja."

Setelah menikah, B merasa banyak hal yang berubah dari pola hidupnya dan pasangan. Perhatian suami dirasakan semakin berkurang terhadap B maupun keluarganya. Tetapi B merasa hal itu kemungkinan karena kesibukan pekerjaan suaminya sebagai sales promotion boy. Waktu luang bersama pasangan juga berkurang, terutama setelah memiliki anak. Mereka jarang menghabiskan waktu berdua. Hal ini sesuai dengan pernyataan Duvall dan Miller (1985) maupun Strong dan DeVault (1989) yang menyatakan bahwa pada umumnya kepuasan pernikahan agak menurun setelah kelahiran anak pertama.

Kehadiran anak membawa kebahagiaan bagi B, dia merasa sangat senang dengan perannya sebagai orangtua. Pada awal menjadi ibu, B harus beradaptasi dengan peran barunya. Meskipun awalnya kesal karena harus sering bangun di malam hari dan harus bangun pagi untuk merawat anak, namun seiring berjalannya waktu, B terbiasa dan menikmati perannya sebagai ibu. Terkait dengan keluarga dan teman, B merasa mengenal seluruh anggota keluarga pasangannya. Namun B lebih merasa nyaman dengan keluarga dari pihak ayah mertuanya yang dirasa sangat baik kepada B dibanding dengan ibu mertua dan keluarga dari pihak ibu mertuanya yang kurang menyukai $\mathrm{B}$ karena dianggap sebagai menantu yang pemalas.

Berhubungan dengan orientasi keagamaan, B merasa tidak ada perbedaan nilai keagamaan antara dia dan suaminya. Bahkan B mengakui A lebih rajin beribadah daripada dirinya. Terkait dengan kesesuaian peran, B juga tidak merasa ada masalah dengan peran yang dia jalankan. Peran di dalam rumah tangga dirasa B cukup adil, B sebagai ibu rumah tangga yang bertugas merawat 
anak dan mengerjakan semua urusan rumah tangga, sedangkan suaminya bekerja di luar rumah menafkahi keluarga.

B menyukai sifat A yang jujur. Termasuk saat ketahuan selingkuh, A menceritakan masalah sebenarnya kepada B.

"yang gue suka dari laki gue dia orang jujur, waktu ketahuan dia sama cewe lain, dia bilang ke gue, ga ngapa-ngapain itu cewe, trus semua gaji yang dia punya, dikasih ke gue."

Perselingkuhan A sangat memengaruhi kepuasan pernikahan B, terutama dalam hal hubungan seksual. Di awal pernikahan, B selalu menerima ajakan suaminya untuk berhubungan seksual. Namun setelah kehadiran anak, B sering menolak ajakan suaminya karena mengaku lebih mengutamakan anak. B menganggap, salah satu alasan suaminya selingkuh kemungkinan karena B sering menolak untuk berhubungan seksual. Selain karena B kurang suka menyediakan makan, minum, dan melayani suaminya saat pulang kerja. Kejadian perselingkuhan suaminya membuat B lebih tidak ingin berhubungan seksual karena merasa sakit hati. Hubungan seksual dianggap penting oleh B, meskipun dia mengaku melakukannya semata-mata untuk memenuhi kepuasan pasangannya.

Hal utama yang memengaruhi kepuasan pernikahan B adalah terkait dengan keuangan. B mengalami kesulitan untuk mengatur keuangan karena merasa pengeluaran keluarganya lebih besar dibanding dengan penghasilan yang diperoleh pasangannya, apalagi B memiliki tanggung jawab untuk membiayai hidup orangtua dan adiknya yang melanjutkan sekolah. B memiliki keinginan mengontrak dan tinggal terpisah dari mertuanya, namun merasa pendapatan yang dimiliki belum mencukupi. B juga memiliki keinginan membantu perekonomian keluarga dengan bekerja, namun dia khawatir tidak ada yang mengurus anaknya jika B bekerja.

\section{Gambaran Partisipan 2}

HB adalah seorang wanita keturunan Arab yang berusia 24 tahun yang memiliki wajah oval, alis mata tebal, dan berhijab. Aktivitas HB sebagai ibu rumah tangga yang mengurusi suami dan anaknya. Usia pernikahan HB baru berjalan 2 tahun. Awal mula HB mengenal suaminya dari sekolah. HB dan P (suami HB) satu sekolah, pada saat itu HB sebagai adik kelasnya P. Ketika P menyatakan cinta pada HB, HB belum sepenuhnya yakin untuk menerima P. Masih adanya 
keraguan dalam benak HB untuk menerimanya karena HB tidak mudah untuk menerima seseorang menjadi pacarnya. HB tipe orang yang pemillih untuk menjalin hubungan. Mereka menjalin hubungan berpacaran selama 5 tahun lamanya.

P mengetahui HB sebagai wanita keturunan Arab yang memang mengharuskan menikah dengan laki-laki keturunan Arab juga, namun mereka masih tetap berhubungan secara sembunyisembunyi. Pihak keluarga P sangat menerima HB. Sebaliknya, keluarga besar HB menolak hubungan HB dengan laki-laki non Arab dan memutuskan untuk tidak hadir ke pernikahan HB dengan P. HB hanya dapat diam, kecewa, dan sedih dengan perlakuan keluarga besarnya. Kedua orangtua HB dapat dikatakan sebagai keluarga yang demokratis, yaitu tidak terlalu mengekang pilihan-pilihan anaknya dalam memilih pasangan hidupnya. Tetapi sebenarnya orangtua HB tetap ingin HB menikah dengan laki-laki keturunan Arab. Namun jika sudah merupakan pilihan HB, orangtua HB tidak dapat berbuat banyak. Alasan HB sangat ingin memperjuangkan $\mathrm{P}$ sampai akhirnya menikah adalah karena HB merasa nyaman dekat dengan P. HB juga melihat pernikahan orangtuanya yang tidak harmonis dan sang ayah sudah memiliki istri lebih dari dua. Peristiwa itulah yang membuat HB merasa bahwa laki-laki Arab adalah orang yang kasar dengan wanita serta kurang memiliki tanggung jawab kepada keluarganya. HB melihat peran ayahnya kurang memberikan contoh yang baik sebagai kepala rumah tangga, sehingga HB pun tidak ingin menikah dengan laki-laki keturunan Arab.

Kemudian HB memiliki pengalaman negatif dengan laki-laki keturunan Arab. Sebelumnya HB pernah menjalin hubungan berpacaran dengan laki-laki keturunan Arab. Tidak lama hanya bertahan beberapa bulan saja dan itu pun ketika HB sedang putus dengan P (yang sekarang menjadi suaminya). Pada saat berpacaran dengan laki-laki keturunan Arab, HB merasa tidak adanya kecocokan dan kenyamanan di antara mereka berdua. HB diperlakukan tidak baik dengan pria tersebut.

\section{Kepuasan Pernikahan Partisipan 2}

Secara umum di seluruh aspek pernikahan, HB merasa puas. HB menilai pasangannya sebagai pribadi yang pendiam, namun sangat bertanggung jawab dan dewasa. Pekerjaannya sebagai karyawan di bidang Migas, membuat $\mathrm{P}$ dapat memenuhi kebutuhan keluarga dengan baik. Perekonomian keluarga tercukupi dengan baik, meskipun ada rencana mereka akan membuka restoran untuk mengembangkan perekonomian keluarga. Komunikasi di antara mereka juga berjalan dengan baik, ketika ada masalah $\mathrm{P}$ selalu berusaha bermusyawarah untuk mencari solusi. 


\section{"Alhamdulillah sejauh ini kesulitan sedikit ya, kita sering evaluasi diri, kalo ada masalah pasti selalu diomongin..."}

Meskipun sudah memiliki anak, namun HB dan P masih menyempatkan untuk jalan berdua, menitipkan anak kepada orangtua P. HB mengaku juga cukup dekat dengan keluarga dan temanteman P, mereka suka menghabiskan waktu bersama. Adik P juga merupakan teman HB untuk mencurahkan isi hati dan beraktivitas. Meskipun ada keinginan untuk bekerja, HB merasa sangat bersyukur dan senang dengan perannya saat ini sebagai ibu rumah tangga yang mengurus anak dan urusan rumah dan suaminya mencari nafkah di luar. Terkait hubungan seksual, HB menganggap hal itu penting untuk mempertahankan keharmonisan rumah tangga, salah satu cara untuk menunjukkan rasa cinta dan menyatukan dua hati. HB mengaku rutin melakukan hubungan seksual dengan suaminya. Hal ini sesuai dengan pernyataan Hunt (dalam Atwater \& Duffy, 2005) yang menganggap bahwa arti hubungan seksual bukan sekedar menghasilkan keturunan, tapi juga dianggap sebagai alat untuk mengekspresikan cinta dan sumber kesenangan yang intens.

Terkait orientasi keagamaan, tidak ada perbedaan yang berarti. Hanya saja keluarga HB dianggapnya lebih dalam dan mengaitkan segala aspek masalah dengan agama, sedangkan tidak demikian dengan suami dan keluarganya. Namun sang suami terlihat sering bertanya mengenai tradisi keislamanan yang dilakukan oleh istrinya. Kekurangpuasan HB terkait dengan pernikahannya lebih terkait dengan ketidakrestuan keluarga besar HB menerima pernikahannya dengan pria non Arab.

\section{DISKUSI}

Peneliti menemukan bahwa perbedaan budaya dalam suatu pernikahan dapat menyebabkan ketidaknyamanan dalam rumah tangga. Meskipun hal tersebut tidak terlalu berarti memengaruhi kehidupan rumah tangga partisipan, namun rasa ketidaknyamanan tersebut masih dirasakan oleh pasangan dan juga masing-masing keluarga besar pasangan. Hal ini sesuai dengan apa yang dikemukakan oleh Monahow (dalam Vaijayanthimala dkk., 2004) serta Spanier dan Glick (dalam Vaijayanthimala dkk., 2004) bahwa pernikahan dengan perbedaan suku atau etnis lebih rentan terhadap konflik. 
Pengalaman pahit yang dirasakan partisipan yang pada akhirnya menikah dengan etnis lain dan membuat kedua partisipan memiliki persepsi negatif pada laki-laki keturunan Arab. Hal ini sesuai dengan yang dikemukakan oleh Rakhmat (2005) bahwa faktor personal dapat memengaruhi persepsi seseorang.

Kedua partisipan dengan masing-masing pasangannya memiliki kesesuaian peran dan harapan yang sama. Seperti seorang istri kodratnya adalah sebagai ibu rumah tangga yang baik dan suami sebagai pekerja keras mencari nafkah untuk keluarga. Pembagian peran tersebut dirasa cukup adil sehingga tercipta rasa kepuasan pernikahan. Kesesuaian peran dan harapan memengaruhi kepuasan pernikahan, hal ini didukung oleh pernyataan Chadwick (dalam Cox, 1978) bahwa kesesuaian peran dan harapan antara pasangan suami istri turut menentukan kepuasan pernikahan. Pasangan yang ingin mempelajari atau ingin memahami kebiasan apa saja yang dimiliki oleh pasangannya itu termasuk faktor-faktor yang mendukung keberhasilan dalam kepuasan pernikahan. Hal ini didukung oleh pernyataan Tseng, Dermott, dan Maretzki (1977) bahwa faktor yang mendukung keberhasilan dalam pernikahan pada pasangan berbeda etnis adalah adanya rasa keinginan untuk saling mempelajari kebudayaan dari pasangan.

Akhirnya mereka kurang memiliki waktu luang bersama sehingga memengaruhi kepuasan pernikahan partisipan karena waktu luang bersama itu memiliki dampak positif untuk kedua pasangan. Hal ini didukung oleh penelitian dari Hawkes, Holman, dan Epperson (dalam Agate, Zabriskie, Agate, \& Poff, 2009) yang menyatakan bahwa lebih dari 70 tahun para peneliti mengidentifikasikan dan menemukan adanya hubungan yang positif antara waktu luang bersama dengan dampak positifnya bagi pasangan. Holman, Holman, Jacquart, dan Miller (dalam Johnson, Zabriskie, \& Hill, 2006) serta Orthner, Smith, Snyder, dan Monsma (dalam Johnson dkk., 2006) juga menemukan secara konsisten bahwa suami istri yang berbagi waktu luang bersama akan lebih puas dengan pernikahannya dibandingkan dengan yang tidak. Hal ini disebabkan karena menurut Agate dkk. (2009) waktu luang dapat memberikan kesempatan bagi keluarga untuk terikat satu sama lain, menyelesaikan masalah, dan memperkuat hubungan.

Berdasarkan berbagai literatur mengenai kepuasan pernikahan, peneliti menemukan bahwa kepuasan pada satu aspek erat kaitannya dengan kepuasan pada aspek lain, terutama pada aspekaspek yang dianggap penting oleh pasangan. Oleh karena itu, peneliti mengalami kesulitan dalam membuat batasan antara aspek yang berbeda namun masih memiliki kaitan. Misalnya dalam aspek komunikasi yang memiliki kaitan dengan kemampuan menyelesaikan masalah, begitu juga dengan aspek kebersamaan yang saling berkaitan dengan aspek keintiman. 


\section{SIMPULAN DAN SARAN}

\section{Simpulan}

Berdasarkan hasil analisis dapat ditarik kesimpulan bahwa kedua partisipan memiliki rasa ketidaknyamanan dalam berumah tangga seperti tidak dapat mengikuti kegiatan-kegiatan bersama keluarga besarnya. Keluarga besar tidak menyetujui pernikahan mereka karena keluarga besar partisipan menganggap pernikahan tersebut sudah melanggar tradisi keluarga besar partisipan. Namun hal ini tidak membuat partisipan merasa tertekan dan masih dapat melakukan aktivitasnya secara normal dan tidak berpengaruh besar terhadap kepuasan pernikahan kedua partisipan. Adanya penyebab yang mendasari kedua partisipan yang pada akhirnya melakukan pernikahan dengan lakilaki non Arab yaitu pengalaman negatif dengan laki-laki Arab dalam kehidupannya. Dapat dikatakan kedua partisipan memiliki persepsi negatif pada laki-laki keturunan Arab.

Perbedaan kebudayaan dalam pernikahan kedua partisipan juga terlihat kurang berpengaruh besar dalam kepuasan pernikahan mereka. Pengaruh besar dalam pernikahan antar kedua partisipan adalah aspek dari kepuasan pernikahan itu sendiri. Faktor utama yang berpengaruh besar dalam kepuasan pernikahan partisipan adalah aspek keuangan atau faktor ekonomi. Faktor ekonomi juga dapat memengaruhi aspek-aspek kepuasan pernikahan lainnya.

Faktor keluarga dalam pernikahan kedua partisipan tidak terlalu memengaruhi kepuasan pernikahan pada masing-masing partisipan, terutama keluarga besar masing-masing partisipan. Kemudian aspek keagamaan tidak memengaruhi kepuasan pernikahan pada partisipan karena kedua partisipan memiliki agama yang sama, hanya saja kebudayaan mereka yang berbeda. Namun untuk pasangan HB sangat memahami dan ingin mempelajari kebudayaan apa yang dijalankan oleh pasangannya. Lain halnya dengan aspek kesesuaian peran, kedua partisipan memiliki kesamaan. Kedua partisipan menerima bahwa sebagai wanita kodratnya harus menjadi ibu dan istri yang baik untuk anak dan suaminya, sedangkan suaminya bekerja mencari nafkah untuk memenuhi kebutuhan keluarga.

\section{Saran Teoretis}


Untuk penelitian selanjutnya dapat melakukan penelitian dengan membandingan kepuasan pernikahan pada wanita keturunan Arab yang melakukan pernikahan dengan laki-laki keturunan Arab dan suku lain. Agar dapat mengetahui, pernikahan mana yang paling tinggi tingkat kepuasan pernikahannya.

\section{Saran Praktis}

Untuk para pasangan yang melakukan pernikahan beda etnis sebaiknya terus mencoba untuk memahami kebiasaan sehari-hari, tradisi-tradisi apa yang dilakukan dan hal-hal yang disukai masing-masing pasangan agar tidak terjadi kesalahpahaman.

\section{REFERENSI}

Agate, J. R., Zabriskie, R. B., Agate, S. T., \& Poff, R. (2009), Family leisure satisfaction and satisfaction with family life. Journal of Leisure Research, 41(2), 205-223.

Almasyhur, I. A. (2002). Sekitar kafa'ah Syarifah dan dasar hukum Syarifahnya. Jakarta: Yayasan Almustarsyidin.

Assagaf, M. H. (2000). Derita putri-putri Nabi: Studi historis kafa'ah Syarifah. Bandung: Remaja Rosdakarya.

Atwater, E., \& Duffy, K. G. (2005). Psychology for living: Adjustment, growth and behavior today (8th ed.). Upper Saddle River, NJ: Pearson.

Cox, F. D. (1978). Human intimacy, marriage, the family and it's meaning. Minnesota, MN: West.

Duvall, E., \& Miller, C. M. (1985). Marriage and family development (6th ed.). New York, NY: Harper \& Row.

Johnson, H., Zabriskie, R., \& Hill, B. (2006). Leisure-activity patterns and marital satisfaction: A futher test. Journal of Marriage and Family, 50(1), 69-77.

Matsumoto, D., \& Juang, L. (2008). Culture and psychology (4th ed.). Boston, MA: Wadsworth Cengage.

Mulia, I. R. (2012). Kedudukan anak perempuan keturunan Sayyid yang menikah dengan laki-laki yang bukan keturunan Sayyid terhadap harta warisan orangtua di desa cikoang kabupaten takalar. (Skripsi tidak dipublikasikan). Universitas Hasanuddin Makassar, Indonesia. 
Olson, D. H., \& Fowers, B. J. (1989). Enrich marital inventory: A discriminant validity and crossvalidity assement. Ditemu dari http://www.prepareenrichcanada.com/studies/study3.html.

Poerwandari, E. K. (2007). Pendekatan kualitatif untuk penelitian perilaku manusia. Jakarta: LPSP3 Fakultas Psikologi Universitas Indonesia.

Putranto, K. (2013). Saat cinta terjegal restu orangtua, ini yang harus dilakukan. Ditemu kembali dari http://wolipop.detik.com/read/2013/01/22/124021/2149372/852/saat-cinta-terjegal-restuorangtua-ini-yang-harus-dilakukan

Rakhmat, J. (2005). Psikologi komunikasi. Bandung: Remaja Rosdakarya.

Santrock, J. W. (2006). Human adjustment. New York, NY: McGraw Hill.

Strong, B., \& DeVault, C. (1989). The marriage and family experience. (4th ed.). St Paul, MN: Wet Pub.

Tseng, W. S., Mc Demott, J. F., \& Maretzki, T. W. (1977). Adjusment in intercultural marriage. Honolulu, HI: The University Press of Hawaii.

Vaijayanthimala, K., Kumari, K. B., \& Panda, B. (2004). Socio-economic heterogomy and marital satisfaction. Journal of Human Ecology, 15(1), 9-11.

Van de Berg, L.W.C. (1989). Hadramaut dan koloni Arab di Nusantara. Jakarta: INIS.

Waite, C. J., \& Gallagher, M. (2000). The case for marriage: Why married people are happier, healthier and better of financially. New York, NY: Broadway Book.

Williams, B. K., Sawyer, S. C., \& Wahlstrom, C. M. (2006). Marriage, families, and intimate relationship: A practical introduction. New York, NY: Pearson. 